\title{
Discrepancies in Financial Performance between Domestic and Foreign Owned Enterprises: The case of Greece
}

\author{
Dionisis Valsamis \\ National and Kapodistrian University of Athens, Department of Economics \\ 5 Stadiou Str., 10562 Athens Greece \\ Tel: 30-210-368-9353Ｅ-mail: dvalsamis@gmail.com \\ Marina-Selini Katsaiti (Corresponding Author) \\ United Arab Emirates University, Department of Economics and Finance \\ P.O. BOX $17555 \mathrm{Al}$ Ain, UAE
}

Tel: 97-15-0493-5132Ｅ-mail: Selini.katsaiti@uaeu.ac.ae

Prof. Panagiotis Petrakis

National and Kapodistrian University of Athens, Department of Economics

5 Stadiou Str., 10562 Athens Greece

Tel: 30-210-368-9353Ｅ-mail: ppetrak@econ.uoa.gr

Received: February 25, 2011

Accepted: March 23, 2011

doi:10.5539/ijef.v3n5p76

\begin{abstract}
This study examines whether there are differences between domestic and foreign owned firms operating in Greece, and in particular it focuses on financial management characteristics of the firms under investigation. The data come from the individual companies' balance sheets for the year 2008. The firms under investigation are grouped into two categories based on the origin of their capital share. Using a non-linear model, we arrive at the following results: foreign enterprises have higher use of capital, manage more financial elements, have more access to long-tern borrowing, while they fall short against domestic firms in short term financing. Finally, foreign firms have higher sales and present greater profitability.
\end{abstract}

Keywords: Financial Management, Investment, Interfirm Comparisons, Financial Performance.

\section{Introduction}

Existing literature has focused on the comparison of performance levels between domestic and foreign owned enterprises. A major study by Buckley and Casson (1976) has shown that:

U.S. multinational firms use more research and development

International firms achieve greater productivity levels than firms operating in a single country In the UK, international manufacturing firms, were more profitable compared to the British firms (1965 and 1969). The comparative analysis of enterprises has focused on a series of traits such as the magnitude of an enterprise, the salaries paid (Greenway et al., 2000), competition intensity (Nickell, 1996), productivity levels (Keay, 2000, Hall and Jones, 1999), export levels (Cohen, 1973) and technology (Nelson, 1991).

Empirical findings report significant discrepancies in the performance levels of domestic and foreign owned enterprises. According to Willmore (1986) it is not surprising that foreign firms achieve higher performance levels when compared to domestic ones, both in developed and developing countries. Among other things, these discrepancies can be attributed to differences in productivity levels, wages, profitability, economic growth, market strategic entry, labor relations, market share, size, innovation and advertising campaign (Bellak, 2001).

The question of interest that we attempt to answer in this study is whether there are differences in the capital structure and performance between Greek and foreign owned enterprises. In order to answer this question we focus on differences in four areas: profitability, growth, managerial ability and solvency. The answer to the posed question is of critical importance especially for the future of the Greek economy. After the integration of Greece in the EU and the EMU several crucial changes took place regarding investment and capital movements. In particular, Greek 
firms as a result are facing greater competition than before. The key to sustainable growth and development of Greek enterprises is financial management. Easy access to external financing in combination with sound financial management could provide a comparative advantage to the domestic owned establishments when compared to foreign ones.

So what is the reason behind the continuous interest of researchers regarding the comparison between domestic and foreign owned establishments?

To start with, societies devote the largest share of their available resources to investment, and in particular into attracting foreign investment. The developing economies are trying to take advantage of the relatively higher performance of foreign owned firms through the diffusion of new technology in the domestic sector. According to the recent literature, the importance of the establishment of new firms in foreign countries is not only attributed to the fact that they can import new technologies, but more importantly to the fact that they can boost economic growth (Keller, 2000). One of the greatest benefits stemming from the domestic economic activity of foreign enterprises is their well-established superior performance compared to the domestic firms. This fact has major implications in the formation of national investment policies. Besides the benefits stemming at the microeconomic level, such investments have positive externalities on social welfare (Hanson, 2001).

Second, the increase in the number of mergers and acquisitions has led to a significant increase in the number of foreign establishment as a share of the total number of firms in the manufacturing and the service sectors. At the same time, as new issues arise regarding the comparison between foreign and domestic owned enterprises, the globalization process has escorted to the dominance of multinational firms in most sectors (Bellak, 2001).

Third, competition at the international level also creates demand for comparisons between domestic and foreign enterprises. In addition, there exists considerable attention regarding performance levels of different organizational structures and management strategies. Last, the comparison between firms or groups of firms with certain characteristics (size, labor force size, organizational structure) creates numerous methodological issues which are investigated by economic analysis.

The following section outlines the relevant literature. Data source and methodology are presented in Section 3. Section 4 presents the results of the empirical estimation and discussion. In Section 5 we conclude.

\section{The literature}

\subsection{Theory}

Economists have long searched for the reason behind foreign activity of enterprises and the existence of multinational enterprises. The first explanations, attempted in the 1970s, were based on the theory of production, and gave emphasis to Foreign Direct Investment (FDI), as the means of financing international production through multinational firms. But, why does FDI take place? The existing literature has tried to answer this question using the arbitrage argument. Interest rates differ from one country to another, creating opportunities for profit. However, so far there is no perfect coincidence between FDI and the growth of multinational firms. In addition, real interest rate discrepancies do not offer a satisfactory interpretation regarding the existence of FDI.

The interest rate interpretation was valid until 1976 when Hymer showed that the then existing theories did not do a sufficient job in explaining the foreign activity of international firms. Hymer developed his own interpretation based on the theory of the firm in conjunction with industrial production (Market Power, Pitelis, 2002). Hymer was followed by Dunning, (1977, 1988), who came up with a group of theoretical approaches known as the "Eclectic Paradigm of International Production" (Dunning 1977,1988).

FDI is a very significant fraction of international movement of capital. The main purpose of FDI is to take over the control of a firm and the formation of multinational and international corporations. So far the literature has not provided a complete explanation regarding the existence of international production.

\subsection{Empirical Evidence}

A number of studies have investigated the performance discrepancies between foreign and domestic owned establishments. The majority of this research focuses on manufacturing due to data availability. Outlon (1998) on the other hand focuses on services. In addition, most studies use data from the US and UK, mainly using as performance indicators productivity and wages.

Most of the empirical literature has focused on productivity gap. Davies $\kappa a l$ Lyons (1991) find that the productivity gap between foreign and domestic firms reaches $20 \%$. This percentage can be broken down to two parts: one is the impact of structure and the second is the impact of ownership. Outlon (1998) measures productivity gap using UK manufacturing data. He finds that productivity in foreign owned is $38 \%$ higher than in domestic owned enterprises. 
Here, capital intensity in production is found to be the main factor driving this gap. Doms kal Jensen (1998) examine domestic multinational firms and foreign owned enterprises and conclude that there is limited impact of ownership on performance. Howenstine $\kappa \alpha$ Z Zeile (1992) underline the tendency of foreign owned firms to have high capital intensity. This fact is an indication for higher labor productivity. Maliranta (1997) on the other hand, using data from Finland, and Griffith (1999), using data from the UK, find a weak impact of ownership on performance. Along the same lines, Moden (1998) finds inconclusive results using data from Sweden. However, Harris (1999) repeats the exercise of Griffith (1999) and reaches the opposite conclusions regarding the existence of productivity gap. Working with Australian data Bellak kal Pfaffermayr (2000) find higher performance of foreign owned establishments compared to domestic.

Numerous studies (Mataloni, 2000, Kumar, 1990;1984, Yiä-Antila and Ali-Yrkkö, 1997, Dickerson et al., 1997) have found significant differences at profitability levels between domestic and foreign enterprises. Profitability in general is a field in which foreign owned enterprises are superior compared to the domestic ones. Kumar (1990) analyzes data from 43 Indian manufacturing companies. He finds that foreign owned enterprises have higher profitability rates mainly due to the protection against entry barriers for the multinational firms and the comparative advantage of knowledge and innovation. Using data from the UK Kumar (1984) shows that foreign activity does not significantly affect profitability or growth of the parent company.

Other empirical research has focused on other indicators of performance. Blanchflower (1984), Globerman et al. (1994), and Outlon (1998) among others, examine the impact of wage gap. The presence of a wage gap is a sign for the existence of a skill gap in labor force, since the skilled employees receive higher salaries than the unskilled ones. Other studies, Carmichael, 1992; Cousineau et al., 1989; Greer kal Shearer, 1981, focus on the discrepancies between foreign and domestic owned firms in labor relations. Those studies reach mixed results, so a single conclusion is not possible. Skill gap has also been under investigation in the literature. Skill gaps are associated with capital intensity and consist a key factor in the creation of productivity differences across the two categories of firms. Howenstine and Zeile (1992) show that foreign owned manufacturing enterprises in the US are mostly active in industries requiring a high level of employee skill. Regarding the existence of a growth gap between domestic and foreign owned enterprises Outlon (1998) reports a positive effect of foreign owned establishments on yearly growth rates firms, value added and capital per worker. Howenstine kal Zeile (1992) and Moden (1998) confirm either weak or no effect of ownership on Research and Development (R\&D) activities. However, Moden (1998) reports that foreign activity is more frequent in companies active in R\&D.

While there was a rapid increase in F.D.I. during the 1990s as well as a redistribution of F.D.Is within the OECD countries, Greece is very much behind in the participation to the international capital movements. This is mainly due to the lack of mergers and acquisitions that took place during that period, since there were no major incentives to attract strategic foreign investors. Between 1980 and 2002, Spain and Portugal, economies similar to Greece, showed an increase in F.D.I. by $1100 \%$ and $4136 \%$ respectively. However, the numbers for Greece are very discouraging. The Greek membership to the EU and the EMU, did not have the expected impact on the amount of F.D.I. inflows, leaving Greece last in the ranking of OECD countries on F.D.I. inflows. According to OECD, in 2007 a mere $0.1 \%$ of the F.D.I capital movements that took place across the OECD countries was invested in Greece.

\section{Empirical Investigation}

\subsection{The Data}

Our data comes from company balance sheets. In particular, we split the data into two samples. The first one includes financial data for 140 Greek enterprises. The second contains data for 140 foreign owned establishments. All data are for the year 2008. The source of this data is ICAP. The categorization of our full sample in domestic and foreign enterprises is done based on the following rule. Enterprises with more than $50 \%$ of their capital share owned by domestic investors are grouped as Greek. Otherwise, they are classified as foreign. The number of firms in each subsample is limited due to data availability.

For the most part, foreign owned enterprises belong to the industrial (total 49) or the trade sectors (total 49), with the rest coming from several other sectors. On the other hand domestic owned establishments belong to a large extent to the service sector, with limited use of new technologies and physical capital.

ICAP data include three variables which give an indication regarding growth rates as well as balance sheets accounts, such as Net Worth, Short-term Debt, Fixed Assets, Inventories, Total Assets and Net Sales. Based on the available data for 2008, we construct 23 financial indicators (see Table 1) according to the methodology of Courtis (1978). 
Table 1 includes all financial ratios found or advocated to be useful by Courtis (1978). There are four main categories: Solvency, Managerial Performance, Profitability and Growth. Each indicator included in those four categories is abbreviated using a code of the form Rt_\#, where \# represents a number.

\subsection{Methodology}

The present study examines whether there are differences in performance between foreign and domestic owned enterprises established in the Greek economy, and whether one can identify the factors which create those discrepancies. This question is of high significance for the future of the Greek economy.

A quick observation of the data allows us to note the superiority of the foreign owned companies when compared to the domestic ones. In particular, the financial performance analysis shows that foreign firms have higher working capital, manage more assets, have more access to Long Term Debt whereas they are in an inferior position compared to the domestic firms in Short Term Debt. Last, foreign enterprises show more sales and greater profitability.

Following Van Der Wijst (1990), the estimation methodology is represented in the following equation:

$$
Y_{i}=b_{1}+b_{2} S_{i} D C_{i}^{b_{3}} A S_{i}^{b_{4}} I T_{i}\left(\exp ^{\sum_{i=1}^{2} b_{61} X_{1, i}}\right)+U_{i}
$$

Where $Y_{i}$ is the dependent variable, here total, short term or long term debt; $S_{i}$ denotes company size, here total assets, $D C_{i}$ is the tax shield, measured as depreciation charges to total costs. $A S_{i}$ indicates asset structure (fixed/total assets), $I T_{i}$ is inventory turnover and $X_{i}$ includes all other explanatory variables. $i$ is the index for the firm category (foreign or domestic) where the firm belongs, $b$ is a vector containing the coefficients of interest and last $U_{i}$ is the error term.

Equation (1) is represents a non-linear relationship between the dependent variable and the regressors. It is estimated using non-linear least squares fit using the Marquardt algorithm (Marquartd, 1963). The above regression model allows for the identification of the determinants of debt for each individual combination of total assets, inventories and capital structure. This model concentrates on identifying the rates of return based on debt structure. The multiplicative specification is deemed to appropriate in this set up mainly due to the fact that the variables under investigation in our specification are expected to influence the proportion rather the amount of debt. In addition, this specification allows for interactions between the variables. The model is deemed suitable for two reasons: first, due to the availability of specific data for the Greek economy that are included in the model and second, due to the fact that this particular model has been adopted for similar estimations regarding the Greek economy (i.e. Voulgaris et al., 2004)

The test for autocorrelation between the explanatory variables rejects the possible existence of autocorrelation in the data. The White Heteroskedasticity test is applied to the model and in the cases where heteroskedasticity is detected it is corrected using the White Criterion.

Tables 7 and 8 contain the regression results regarding the short term, long term and total debt for domestic and foreign owned enterprises accordingly. For both categories of firms, the general specification of the model is included. The estimation methodology leads to a more parsimonious model after the exclusion of the parameters which are not found to be statistically significant (at the $5 \%$ level).

\section{Empirical Results}

This section presents and analyzes our empirical results. In particular, we examine the factors which determine growth for the firm and more generally the rate of return of foreign and domestic owned enterprises, based on their capital structure.

\subsection{Greek Enterprises}

The regression results (Table 2) for the domestic owned enterprises, reveal significant and sizable impact for most of the financial indices included in the analysis. The most sizable effects appear on total debt.

Regarding regression (1) results point to a positive effect of (i) size, measured in terms of Total Assets, (ii) Net Working Capita/Total Assets (Rt_3) and (iii) Fixed Assets/Total Assets (Rt_4) on Total Debt/Total Assets. This finding is in perfect agreement with the Asymmetric Information Theory (AIT). The AIT argues for the existence of a positive relationship between debt and capital structure. In addition, it claims that firms of bigger size have more access to financial intermediation (short term and long term loans) due to easy access to capital markets and the existence of collaterals for borrowing. In addition, according to that theory, information asymmetries and moral hazard are greater for small sized enterprises, due to their ownership structure and the lack of financial transparency. 
The high cost of borrowing in Greece is a factor which deters borrowing conditions mainly for SME's, while the tight fiscal policy followed by the Greek government deteriorates the investment conditions.

Besides Total Debt, what we observe is a positive relationship between long term debt and total assets, whereas for short term debt this relationship is not statistically significant (at the $5 \%$ level). In general we see that Greek firms tend to use more short term borrowing in order to promote their sales and finance their operating costs, mainly due to their limited access to long tern borrowing.

Growth, when measured as percentage change in Total Assets (Rt 24) doesn't appear to have a significant effect on borrowing. This conclusion is in contrast with the theory where small but rapidly growing enterprises, like the Greek ones, lack resources for the financing of their boosted needs. In addition, difficult access to capital markets and long term borrowing leads to greater use of short term borrowing. Probably this result is due to the fact that our analysis is cross sectional with not time dimension.

With regards to profitability, which is measured using Rt_22, Net Profit/Total Assets, we find a negative impact on short term and long term debt. The negative sign here can be interpreted using the theories of representative cost. In particular, according to the "Pecking Order Framework" (POF) theory firms finance their business plans through internal financing. However, if this is not a possibility for the firm then they are led to external borrowing using safer financial products. Again, if this is not a choice either a third solution is the issuing of new stocks. This is the interpretation behind the negative relationship between profitability and long term borrowing. This result agrees with the results of Kaplan and Urwitz (1979), Kester (1986), Van der Wijst and Turik (1993), Chitenden et al. (1996), Michaelas et al. (1999), Mira (2002).

Liquidity, when measured as Working Capital / Total Assets (Rt_3), is found to have a negative effect on Total Debt, a result which is in agreement with the POF theory. Net Working Capital requires capital controls for a long time, which, in the case of Greek enterprises, can be either own capital or profits which are reinvested.

Inventory is our next variable of interest. While in the long run inventory is statistically significant and has a positive sign, in the short term it has a negative effect. The interpretation of this fact is probably lying on the fact that inventories in Greek enterprises are often thought to be associated with inefficient management, and for the most part are risky for the creditors.

These results imply that total assets are positively related with long term and total debt. Hence more assets allow greater borrowing through collaterals. On the other hand, banks reduce the risk of defaulting on their obligations due to the size of Total Assets of their debtors. This finding is in perfect accordance with previous studies, i.e. Michaelas et al., 1999).

The percentage (\%) change in sales, net profit (Rt_25), and total assets (Rt_23), does not seem to have a statistically significant effect on all different types of Debt, which is in disagreement with the conclusions of similar studies (Vouglaris, 2004).

\subsection{Foreign Owned Enterprises}

The findings of the regressions for foreign own enterprises are shown in Table 3.

As we observe, the variables which are found to be statistically significant at the $5 \%$ level are: Total Assets, Total Working Capital to Total Assets (Rt_3), Long Term Debt plus Net Worth to Fixed Assets (Rt_5), Fixed Assets to Total Assets (Rt_4), Inventory (Rt_10), Net Salws to Fixed Assets (Rt_13), Net Sales to Total Assets (Rt_15), Net Sales to No of Employess (Rt_18), Net Profit to Net Worth (Rt_21), \% change in Total Assets (Rt_24) and Net Profit to Total Assets (Rt_22).

Profitability, when measured by Rt_22 has a negative relationship with Total Debt, which supports the POF theory. As profitability increases, firm needs for external financing shrink, since part of their profit is used towards investment. We have to note at this point that profitability affects the structure of debt duration. Although net profit is an important determinant of total borrowing in the long run, this result does not seem to hold for the short term debt. The positive effect of profitability on long term debt can be interpreted by the fact that foreign enterprises prefer to use external financing for their growth in order to take advantage of the lower tax burden, while at the same time they can provide dividends to their shareholders.

For foreign firms, Total Assets growth positively affects long term profit but has no effect neither on short term not on total debt. This shows that rapidly growing enterprises use loanable funds in order to service their needs for cash. According to the POF, given the higher capital cost, foreign owned establishments might use larger borrowing short or long term. 
Total assets affect only short term profit and do not appear to be statistically significant in the regressions that control for other forms of debt. Total assets impact short term debt mainly due to the fact that foreign enterprises either reinvest using their profit or "import" funds from their parent company in the form of FDI. Short term capital use is done for practical reasons, such as financing sudden needs, unforeseen by the administration.

With regards to the managerial performance of the foreign enterprises, measured as Fixed Assets to Total Assets (Rt_4) and Inventory (Rt_10) we reach the following results. There is a negative impact of Rt_4 on Short Term and Total Debt, while the opposite is true for the Long Term Debt. Concerning Rt_10 we observe a positive impact on Short Term Debt. This finding proves for the foreign enterprises the existence of reasonable management structure and accurate planning, which is key in their development and growth.

Last, with regards to liquidity (Rt_3) the regression estimations reveal a negative effect on Total and Short Term Debt but a positive one on Long Term Debt.

\section{Conclusions}

In the present study we examine several factors which determine financial performance. In particular, we analyze capital and debt structure. We investigate two groups of enterprises operating in the Greek economy, domestic and foreign owned, based on their capital shares. The following results hold for both categories of firms: debt is positively associated with total assets; debt is increasing in net sales; liquidity is decreasing in debt; debt is decreasing in profitability.

The differences between domestic and foreign enterprises can be summarized in the following:

For foreign owned firms we find a positive relationship between Inventory and Short Term Debt, whereas for domestic enterprises this relationship is negative. This probably indicates the hesitation of banks to provide borrowing in the presence of large inventories, because they consider them a result of inefficient management.

For foreign owned enterprises, size is an important factor for short term debt. On the contrary, for Greek enterprises the volume of Total Assets is associated with Long Term and Total Debt.

Growth, measured as \% change in Total Assets, leads to higher Long Term Debt for foreign firms, whereas this relationship is not statistically significant for the Greek firms.

Higher profit margins result in higher use of Short and Long Term Debt only for domestic firms.

Management performance, measured as (i) Net Worth to Long Term Capital and (ii) the Creditor *360/ Net Sales index, impacts all types of Debt obligations for the Greek firms. This result does not hold for the foreign companies.

Productivity, measured as Total Sales to No of Employees does not return a statistically significant impact on Debt Structure for domestic enterprises, contrary to the foreign ones.

\section{References}

Bellak, C. (2001). How Domestic and Foreign Firms Differ and Why does it Matter? Journal of Economic Surveys, vol. 18(4), pages 483-514, 09 .

Bellak, C., M. Pfaffermayr (2000). Why foreign-owned firms are different: A conceptual framework and empirical evidence for Austria. HWWA Discussion Paper, 115, Hamburg.

Blanchflower, D. (1984). Comparative Pay Levels in Domestically-owned and Foreign-owned Manufacturing Plants: A Comment. British Journal ofIndustrial Relations, vol. 22, 265-267.

Buckley, P.J., Casson, M. (1976). The Future of the Multinational Enterprise, Basingstoke: MacMillan.

Carmichael, F. (1992). Multinational Enterprise and Strikes: Theory and Evidence. Scottish Journal of Political Economy, vol. 39 (1), February, 52-68, doi:10.1111/j.1467-9485.1992.tb00604.x, http://dx.doi.org/10.1111/j.1467-9485.1992.tb00604.x

Cohen, B.I. (1973). Comparative Behavior of Foreign and Domestic Export Firms in a Developing Economy. Review of Economics and Statistics, vol. 55, 190-197, doi:10.2307/1926993, http://dx.doi.org/10.2307/1926993

Courtis, K.J., (1978). Modeling a Financial Ratios Categoric Framework, Journal of Business Finance and Accounting, (Winter), 372-386.

Cousineau, J.-M., R. Lacroix, and D. Vachon (1989). Foreign Ownership and Strike Activity in Canada, Working Paper 89/27, Department of Economics, University of Montreal.

Davies, S.W., B.R. Lyons (1991). Characterising Relative Performance: The Productivity Advantage of Foreign Owned Firms in the UK, Oxford Economic Papers, vol. 43, 584-595. 
Dickerson, A.P., Gibson, H.D. and Tsakalotos, E. (1997). The Impact of Acquisitions on Company Performance: Evidence from a Large Panel of UK Firms. Oxford Economic Papers, vol. 49, 344-361.

Doms, M.E., J.B. Jensen (1998). Comparing Wages, Skills, and Productivity between Domestically and Foreign-Owned Manufacturing Establishments in the United States. In Baldwin, R.E., R.E. Lipsey, and J.D. Richardson (eds) Geography and Ownership as Bases for Economic Accounting, Studies in Income and Wealth, vol. $59,235-255$.

Dunning, J.H. (1977). Trade, location of economic activity, and the MNE: A search for an eclectic approach. In: The International Allocation of Economic Activity, Ohlin, B., Hesselborn, P.-O. and Wijkman, P.M. (eds), London: Macmillan.

Dunning, J.H. (1988). The eclectic paradigm of international production: An update and a reply to its critics. Journal of International Business Studies, vol. 19,1 Spring, doi:10.1057/palgrave.jibs.8490372, http://dx.doi.org/10.1057/palgrave.jibs. 8490372

Globerman, Steven, John C. Ries and Ilan Vertinsky (1994). The economic performance of foreign affiliates in Canada. Canadian Journal of Economics XXVII (1), 143-156, doi:10.2307/135807, http://dx.doi.org/10.2307/135807

Greer, C.R., J.C. Shearer (1981). Do Foreign-Owned Firms Practice Unconventional Labor Relations? Monthly Labor Review, vol. 104, 44-48

Griffith, R. (1999). Productivity and Foreign Ownership in the UK CarIndustry, The Institute for Fiscal Studies, Working Paper Series No. W99/11.

Hall, R., Jones, C. (1999). Why do some countries produce so much more output per worker than others. Quarterly Journal of Economics CXIV, 83-116, doi:10.1162/003355399555954, http://dx.doi.org/10.1162/003355399555954

Hanson, G.J. (2001). Should Countries Promote Foreign Direct Investment? G-24 Discussion Paper Series, No. 9 , February.

Harris, R.I.D. (1999). Foreign Ownership and Productivity in the United Kingdom - Some Issues When Using the ARD Establishment Level Data, IFS Working Paper, No. W99/06.

Howenstine, N.G., W.J. Zeile (1992). Foreign Direct Investment in the United Stages: Establishment Data for 1987. Survey of Current Business, October, 44-58.

Hymer, S. (1976). The International Operations of National Firms: A Study of Direct Investments. Cambridge, Mass: MIT Press.

Kaplan, R., Urwitz, G. (1979). Statistical Models of Bond Ratings: A Methodological Inquiry. Journal of Business, vol. 76, 323-329.

Keay, I. (2000). Canadian manufacturers' relative productivity performance, 1907-1990. Canadian Journal of Economics, vol. 33 (4), 1049-1068, doi:10.1111/0008-4085.00053, http://dx.doi.org/0008-4085.00053

Keller, W. (2000). Do Trade Patterns and Technology Flows Affect Productivity Growth? The World Bank Economic Review, vol. 14 (1), 17-47.

Kester, W. C. (1986). Capital and Ownership Strucure: A Comparison of United States and Japanese Manufacturing Corporations. Financial Management, 5-16, doi:10.2307/3665273, http://dx.doi.org/10.2307/3665273

Kumar, M.S. (1984). Comparative Analysis of UK Domestic and International Firms. Journal of Economic Studies, vol. 11 (3), 26-42, doi:10.1108/eb002581, http://dx.doi.org/10.1108/eb002581

Kumar, N. (1990). Mobility Barriers and Profitability of Multinational and Local Enterprises in Indian Manufacturing. The Journal of Industrial Economics XXXVIII (4), 449-463, doi:10.2307/2098350, http://dx.doi.org/10.2307/2098350

Maliranta, M. (1997). Plant Productivity in Finnish Manufacturing, ETLA Discussion Papers, No. 612, Helsinki.

Marquardt, D. (1963). An Algorithm for Least Squares Estimation of Non-Linear Parameters. Journal of Social Industrial and Applied Mathematics.

Mataloni, R.J. (2000). An Examination of the Low Rates of Return of Foreign- Owned U.S. Companies. Survey of Current Business, March, 55-73.

Michaelas, N., Chittenden, F., Poutsiouris (1999). Financial Policy and Capital Structure Choice in UK SMEs: Empirical Evidence from Company Pnel Data. Small Business Economics, vol. 12, 113-130, doi:10.1023/A:1008010724051, http://dx.doi.org/10.1023/A:1008010724051 
Mira, S. F. 92002). On Capital Structure in the Small and Medium Enterprises: The Spanish Case. Instituto de Estudios Europeos, Universidad San Pablo-CEU.

Moden, K.-M. (1998). Foreign acquisitions of Swedish companies: Effects on R\&D and Productivity, mimeographed, IUI: Stockholm.

Nelson, R. (1991). Why Do Firms Differ, and How Does It Matter? Strategic Management Journal, vol. 14, 61-74, doi:10.1002/smj.4250121006, http://dx.doi.org/10.1002/smj.4250121006

Nickell, S.J. (1996). Competition and Corporate Performance. Journal of Political Economy, vol. 104 (4), 724-746, doi:10.1086/262040, http://dx.doi.org/10.1086/262040

OECD (2009). Factbook 2009.

Oulton, N. (1998). Investment, Capital and Foreign Ownership in UK Manufacturing, NIESR Discussion Paper, No. 141, August.

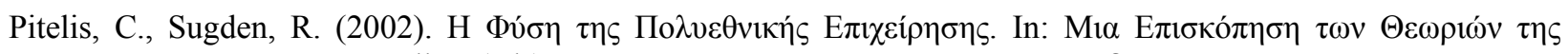

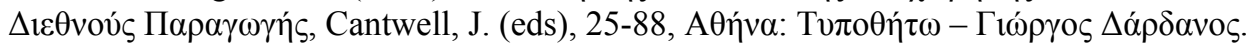

Van Der Wijst, N. (1990). Modeling Interfirm Comparisons in Small Business. Omega International Journal of Management Science, vol. $18, \quad 123-129, \quad$ doi:10.1016/0305-0483(90)90059-I, http://dx.doi.org/10.1016/0305-0483(90)90059-I

Van Der Wijst, N., Turik, R. (1993). Determinants of small firms debt ratios: a analysis of retails panel data. Small Business Economics, vol. 5, 55-65, doi:10.1007/BF01539318, http://dx.doi.org/10.1007/BF01539318

Voulgaris, F., Asteriou, D., Agiomirgianakis, G. (2004). Size and Determinants of Capital Structure in the Greek Manufacturing Sector.

Willmore, L. (1986). The Comparative Performance of Foreign and Domestic Firms in Brazil. World Development, vol. 14 (4), 489-502.doi:10.1016/0305-750X(86)90065-3, http://dx.doi.org/10.1016/0305-750X(86)90065-3

Table 1. Financial Ratios Found to be useful in Predictive Studies

\begin{tabular}{|c|c|c|}
\hline Category & & Index \\
\hline \multicolumn{3}{|l|}{ 1. Solvency } \\
\hline (a) Short-Term Liquidity & Rt_3 & Net Working Capital / Total Assets \\
\hline (b) Long-Term Solvency & Rt_5 & Long Term Debt plus Net Worth / Fixed Assets \\
\hline \multicolumn{3}{|l|}{ 2. Managerial Performance } \\
\hline \multirow[t]{5}{*}{ (a) Asset Equity Structure } & Rt_4 & Fixed Assets / Total Assets \\
\hline & Rt_6 & Long Term Debt / Total Debt \\
\hline & Rt_7 & Total Debt / Total Assets \\
\hline & Rt_8 & Net worth / Long Term Capital \\
\hline & Rt_9 & Short Term Debt / Total Assets \\
\hline (b) Inventory & Rt_10 & Inventory $* 360 /$ Net Sales \\
\hline \multirow[t]{2}{*}{ (c) Credit Policy } & Rt_11 & Creditors $* 360 /$ Sales \\
\hline & Rt_12 & Accounts payable*360/ Net Sales \\
\hline (d) Administration & Rt_18 & Net sales / No of Employees \\
\hline \multicolumn{3}{|l|}{ 3. Profitability } \\
\hline \multirow[t]{4}{*}{ (a) Capital Turnover } & Rt_13 & Net Sales / Fixed Assets \\
\hline & Rt_14 & Net Sales / Net Working Capital \\
\hline & Rt_15 & Net Income / Total Assets \\
\hline & Rt_16 & Net Sales / Net Worth \\
\hline \multirow[t]{3}{*}{ (b) Profit Margin } & Rt_17 & Net Profit/ Gross Profit \\
\hline & Rt_19 & Net Profit / Net Sales \\
\hline & Rt_20 & Gross Profits / Net sales \\
\hline \multirow[t]{2}{*}{ (c) Return on Investment } & Rt_21 & Net Profit / Net Worth \\
\hline & Rt_22 & Net Profit / Total Assets \\
\hline \multicolumn{3}{|l|}{ 4. Growth } \\
\hline & Rt_23 & $\%$ change in Net Sales \\
\hline & Rt_24 & $\%$ change in Total Assets \\
\hline & Rt_25 & $\%$ change in Net Profit \\
\hline
\end{tabular}


Table 2. Regression Results for Greek Enterprises

\begin{tabular}{|c|c|c|c|c|}
\hline Regressions: & 01 & $\mathbf{0 2}$ & $\mathbf{0 3}$ & 04 \\
\hline Dependent Variable $\rightarrow$ & $\begin{array}{c}\text { Total Debt/ Total } \\
\text { Assets } R t_{-} \text {- }\end{array}$ & $\begin{array}{c}\text { Short-Term Debt / } \\
\text { Total Assets Rt_9 }\end{array}$ & \multicolumn{2}{|c|}{$\begin{array}{c}\text { Long Term Debt/ Total Debt } \\
\text { Rt_6 }\end{array}$} \\
\hline Intercept & $\begin{array}{l}1,00106 \\
(19,11)^{*}\end{array}$ & $\begin{array}{c}0,6131 \\
(11,55)^{*}\end{array}$ & $\begin{array}{l}-0,1044 \\
(-2,37)^{*}\end{array}$ & $\begin{array}{r}-0,0045 \\
(-0,16) \\
\end{array}$ \\
\hline Size: Total assets & $\begin{array}{c}7,98 \mathrm{E}-11 \\
(3,34)^{*}\end{array}$ & $\begin{array}{c}-4,62 \mathrm{E}-11 \\
(-1,05) \\
\end{array}$ & $\begin{array}{c}6,61 \mathrm{E}-11 \\
(2,63)^{*}\end{array}$ & $\begin{array}{c}8,54 \mathrm{E}-11 \\
(2,27)^{*}\end{array}$ \\
\hline Net Working Capital/ Total Assets $R t_{-} 3$ & $\begin{array}{l}-0,67059 \\
(-3,60)^{*}\end{array}$ & - & $\begin{array}{l}0,46107 \\
(4,84)^{*}\end{array}$ & - \\
\hline Fixed Assets/Total Assets Rt_4 & $\begin{array}{l}-0,60221 \\
(-5,60)^{*} \\
\end{array}$ & $\begin{array}{l}-0,4379 \\
(-4,72)^{*}\end{array}$ & $\begin{array}{l}0,82554 \\
(10,29)^{*}\end{array}$ & $\begin{array}{l}0,60380 \\
(8,65)^{*}\end{array}$ \\
\hline $\begin{array}{l}\text { Long Term Debt plus net Worth to Fixed } \\
\text { Assets } R t \_5\end{array}$ & $\begin{array}{c}0,00635 \\
(1,57) \\
\end{array}$ & - & - & - \\
\hline Net Worth/Long Term Capital Rt_s & $\begin{array}{l}- \\
-\end{array}$ & $\begin{array}{l}-0,0060 \\
(-2,41)^{*}\end{array}$ & $\begin{array}{l}-0,0027 \\
(-1,94)\end{array}$ & - \\
\hline Inventory $* \mathbf{3 6 0}$ / Net Sales $R t_{-} 10$ & $\begin{array}{c}3,67 \mathrm{E}-05 \\
(1,04)\end{array}$ & $\begin{array}{l}-0,0002 \\
(-2,04)^{*}\end{array}$ & $\begin{array}{c}4,42 \mathrm{E}-06 \\
(2,16)^{*}\end{array}$ & $\begin{array}{l}2,66 \mathrm{E}-05 \\
(5,402)^{*}\end{array}$ \\
\hline Creditors*360/ Net Sales $R t_{-} 11$ & - & $\begin{array}{l}0,0006 \\
(3,22)^{*}\end{array}$ & - & - \\
\hline Accounts Payable *360/ Net Sales $R t_{-} 12$ & - & $\begin{array}{r}0,0003 \\
(1,85) \\
\end{array}$ & - & $\begin{array}{l}- \\
- \\
\end{array}$ \\
\hline Net Sales to Fixed Assets $R t \_13$ & $\begin{array}{l}0,00146 \\
(0,708) \\
\end{array}$ & $\begin{array}{l}0,0075 \\
(2,96)^{*}\end{array}$ & $\begin{array}{l}0,0021 \\
(2,11)^{*}\end{array}$ & $\begin{array}{l}- \\
- \\
\end{array}$ \\
\hline Net Sales to Net Working Capital $R t_{-} 14$ & $\begin{array}{c}8,75 \mathrm{E}-06 \\
(0,21)\end{array}$ & $\begin{array}{c}-1,84 \mathrm{E}-05 \\
(-0,37)\end{array}$ & - & - \\
\hline Net Sales to Total Assets $R t_{-} 15$ & - & - & - & - \\
\hline Net Profit to Gross Profit $R t \_17$ & - & $\begin{array}{l}- \\
- \\
\end{array}$ & $\begin{array}{c}0,01004 \\
(6,15)^{*}\end{array}$ & $\begin{array}{l}- \\
-\end{array}$ \\
\hline Net Sales to No of Employees $R t \_18$ & $\begin{array}{c}-1,6 \mathrm{E}-08 \\
(-0,805)\end{array}$ & $\begin{array}{c}-9,32 \mathrm{E}- \\
09 \\
(-0,58) \\
\end{array}$ & $\begin{array}{c}3,00 \mathrm{E}-10 \\
(0,02)\end{array}$ & $\begin{array}{c}-6,57 \mathrm{E}-10 \\
(-0,15)\end{array}$ \\
\hline Net Profit to Net Sales $R t_{-} 19$ & $\begin{array}{c}-0,13691 \\
(-0,78) \\
\end{array}$ & $\begin{array}{l}0,12381 \\
(3,54)^{*}\end{array}$ & - & $\begin{array}{l}-0,0709 \\
(-3,04)^{*} \\
\end{array}$ \\
\hline Gross Profit to Net Sales Rt_20 & - & $\begin{array}{l}- \\
- \\
\end{array}$ & $\begin{array}{l}-0,0415 \\
(-1,88) \\
\end{array}$ & $\begin{array}{l}- \\
- \\
\end{array}$ \\
\hline Net Profit to Net Worth $R t \_21$ & $\begin{array}{c}0,02883 \\
(1,57) \\
\end{array}$ & $\begin{array}{l}- \\
-\end{array}$ & $\begin{array}{c}0,01321 \\
(1,505)\end{array}$ & - \\
\hline Net Profit to Total Assets $R t \_22$ & $\begin{array}{c}-1,10085 \\
(-1,64) \\
\end{array}$ & $\begin{array}{l}-0,7696 \\
(-5,11)^{*}\end{array}$ & $\begin{array}{l}-0,3944 \\
(-4,13)^{*}\end{array}$ & - \\
\hline \% Change in Net Sales $R t \_23$ & $\begin{array}{c}9,71 \mathrm{E}-05 \\
(0,44)\end{array}$ & $\begin{array}{c}3,27 \mathrm{E}-05 \\
(0,05)\end{array}$ & $\begin{array}{c}0,00027 \\
(1,22) \\
\end{array}$ & $\begin{array}{c}4,53 \mathrm{E}-05 \\
(0,89)\end{array}$ \\
\hline \% Change in Total Assets Rt_24 & $\begin{array}{c}-0,00031 \\
(-1,02) \\
\end{array}$ & $\begin{array}{c}0,00017 \\
(0,309) \\
\end{array}$ & $\begin{array}{r}-0,0005 \\
(-1,71) \\
\end{array}$ & - \\
\hline$\%$ Change in Net Profit $R t \_25$ & $\begin{array}{c}5,35 \mathrm{E}-05 \\
(1,72) \\
\end{array}$ & - & $\begin{array}{c}2,26 \mathrm{E}-05 \\
(1,31) \\
\end{array}$ & $\begin{array}{l}- \\
- \\
\end{array}$ \\
\hline $\mathbf{R}^{2}$ & 0,66 & 0,68 & 0,67 & 0,50 \\
\hline
\end{tabular}

-t-stats appear in parenthesis below the coefficients of interest.

- * denotes Statistical Significance at the 5\% level. 
Table 3. Regression Results for Foreign Enterprises

\begin{tabular}{|c|c|c|c|c|}
\hline Regressions: & 01 & 02 & $\mathbf{0 3}$ & 04 \\
\hline Dependent Variable $\rightarrow$ & $\begin{array}{c}\text { Total Debt/ Total } \\
\text { Assets } R t_{-} 7\end{array}$ & $\begin{array}{c}\text { Short-Term Debt / } \\
\text { Total Assets } R t_{-} 9\end{array}$ & \multicolumn{2}{|c|}{$\begin{array}{c}\text { Long Term Debt/ Total Debt } \\
\text { Rt_6 }\end{array}$} \\
\hline Intercept & $\begin{array}{c}1,0032 \\
(51,89)^{*}\end{array}$ & $\begin{array}{l}0,6896 \\
(5,78)^{*}\end{array}$ & $\begin{array}{c}0,01554 \\
(0,22)\end{array}$ & $\begin{array}{c}-0,0219 \\
(-0,45) \\
\end{array}$ \\
\hline Size: Total assets & $\begin{array}{c}6,46 \mathrm{E}-11 \\
(0,606) \\
\end{array}$ & $\begin{array}{c}1,06 \mathrm{E}-11 \\
(2,39)^{*}\end{array}$ & $\begin{array}{c}6,09 \mathrm{E}-11 \\
(0,63) \\
\end{array}$ & $\begin{array}{c}6,45 \mathrm{E}-11 \\
(0,65) \\
\end{array}$ \\
\hline Net Working Capital/ Total Assets $R t_{-} 3$ & $\begin{array}{c}-0,761 \\
(-15,1)^{*}\end{array}$ & $\begin{array}{l}-0,8604 \\
(-12,1)^{*} \\
\end{array}$ & $\begin{array}{l}0,57218 \\
(6,84)^{*}\end{array}$ & $\begin{array}{l}0,46278 \\
(5,59)^{*}\end{array}$ \\
\hline Fixed Assets/Total Assets Rt_4 & $\begin{array}{l}-0,6605 \\
(-11,2)^{*}\end{array}$ & $\begin{array}{l}-0,7212 \\
(-6,73)^{*} \\
\end{array}$ & $\begin{array}{l}0,64227 \\
(7,78)^{*} \\
\end{array}$ & $\begin{array}{l}0,62271 \\
(7,25)^{*} \\
\end{array}$ \\
\hline $\begin{array}{l}\text { Long Term Debt plus net Worth to Fixed } \\
\text { Assets } R t \text { _ } 5\end{array}$ & - & $\begin{array}{l}0,00064 \\
(1,98)^{*}\end{array}$ & - & $\begin{array}{c}5,05 \mathrm{E}-05 \\
(0,09) \\
\end{array}$ \\
\hline Net Worth/Long Term Capital Rt_8 & - & - & - & - \\
\hline Inventory $* 360 /$ Net Sales $R t_{-} 10$ & $\begin{array}{c}0,00012 \\
(0,52) \\
\end{array}$ & $\begin{array}{l}0,0009 \\
(2,26)^{*}\end{array}$ & $\begin{array}{c}6,00 \mathrm{E}-06 \\
(0,01)\end{array}$ & $\begin{array}{c}0,00018 \\
(0,61) \\
\end{array}$ \\
\hline Creditors*360/ Net Sales $R t_{-} 11$ & $\begin{array}{l}- \\
- \\
\end{array}$ & $\begin{array}{l}- \\
- \\
\end{array}$ & - & $\begin{array}{l}- \\
- \\
\end{array}$ \\
\hline Accounts Payable *360/ Net Sales $R t_{-} 12$ & $\begin{array}{l}- \\
- \\
\end{array}$ & $\begin{array}{c}0,00018 \\
(1,63) \\
\end{array}$ & $\begin{array}{l}- \\
- \\
\end{array}$ & $\begin{array}{l}- \\
- \\
\end{array}$ \\
\hline Net Sales to Fixed Assets $R t_{-} 13$ & $\begin{array}{c}0,00013 \\
(9,71)^{*}\end{array}$ & $\begin{array}{l}0,00011 \\
(2,009)^{*}\end{array}$ & $\begin{array}{c}0,00013 \\
(5,22)^{*}\end{array}$ & $\begin{array}{c}0,00014 \\
(1,38)\end{array}$ \\
\hline Net Sales to Net Working Capital $R t_{-} 14$ & $\begin{array}{c}3,43 \mathrm{E}-06 \\
(0,17)\end{array}$ & $\begin{array}{l}- \\
-\end{array}$ & $\begin{array}{l}-0,0001 \\
(-0,46) \\
\end{array}$ & $\begin{array}{c}4,19 \mathrm{E} 05 \\
(-0,17)\end{array}$ \\
\hline Net Sales to Total Assets $R t_{-} 15$ & - & $\begin{array}{l}0,09493 \\
(2,53)^{*}\end{array}$ & $\begin{array}{c}-0,0133 \\
(-0,70) \\
\end{array}$ & - \\
\hline Net Profit to Gross Profit $R t_{-} 17$ & $\begin{array}{l}- \\
-\end{array}$ & $\begin{array}{l}- \\
-\end{array}$ & $\begin{array}{c}-0,0138 \\
(-0,85) \\
\end{array}$ & $\begin{array}{l}- \\
-\end{array}$ \\
\hline Net Sales to No of Employees $R t \_18$ & $\begin{array}{c}\text { 7,47E-09 } \\
(0,47)\end{array}$ & $\begin{array}{l}-6,2 \mathrm{E}-08 \\
(-2,30)^{*}\end{array}$ & $\begin{array}{c}4,25 \mathrm{E}-09 \\
(0,25)\end{array}$ & $\begin{array}{c}3,90 \mathrm{E}-10 \\
(0,02)\end{array}$ \\
\hline Net Profit to Net Sales $R t_{-} 19$ & $\begin{array}{c}0,01417 \\
(0,11)\end{array}$ & $\begin{array}{c}-0,0069 \\
(-0,07)\end{array}$ & $\begin{array}{c}0,32889 \\
(1,91)\end{array}$ & $\begin{array}{c}0,07343 \\
(0,48)\end{array}$ \\
\hline Gross Profit to Net Sales $R t \_20$ & $\begin{array}{l}- \\
- \\
\end{array}$ & $\begin{array}{l}- \\
-\end{array}$ & $\begin{array}{l}-0,1414 \\
(-1,27)\end{array}$ & $\begin{array}{c}-0,1048 \\
(-0,99) \\
\end{array}$ \\
\hline Net Profit to Net Worth $R t_{-} 21$ & $\begin{array}{l}- \\
-\end{array}$ & $\begin{array}{l}- \\
- \\
\end{array}$ & $\begin{array}{l}0,0389 \\
(2,09)^{*} \\
\end{array}$ & $\begin{array}{l}- \\
-\end{array}$ \\
\hline Net Profit to Total Assets $R t \_22$ & $\begin{array}{l}-0,3047 \\
(-2,70)^{*}\end{array}$ & $\begin{array}{c}-0,0271 \\
(-0,27) \\
\end{array}$ & $\begin{array}{l}-0,7514 \\
(-3,15)^{*}\end{array}$ & $\begin{array}{l}-0,3538 \\
(-2,04)^{*}\end{array}$ \\
\hline \% Change in Net Sales $R t \_23$ & - & $\begin{array}{c}0,00012 \\
(0,29) \\
\end{array}$ & - & $\begin{array}{c}-0,0001 \\
(-0,35) \\
\end{array}$ \\
\hline \% Change in Total Assets $R t \_24$ & - & $\begin{array}{c}0,00044 \\
(1,01)\end{array}$ & - & $\begin{array}{l}0,00091 \\
(2,09)^{*}\end{array}$ \\
\hline \% Change in Net Profit $R t \_25$ & $\begin{array}{c}2,36 \mathrm{E}-05 \\
(0,36)\end{array}$ & - & - & $\begin{array}{c}3,49 \mathrm{E}-05 \\
(0,59)\end{array}$ \\
\hline $\mathbf{R}^{2}$ & 0,79 & 0,83 & 0,54 & 0,52 \\
\hline
\end{tabular}

-t-stats appear in parenthesis below the coefficients of interest.

- * denotes Statistical Significance at the 5\% level. 